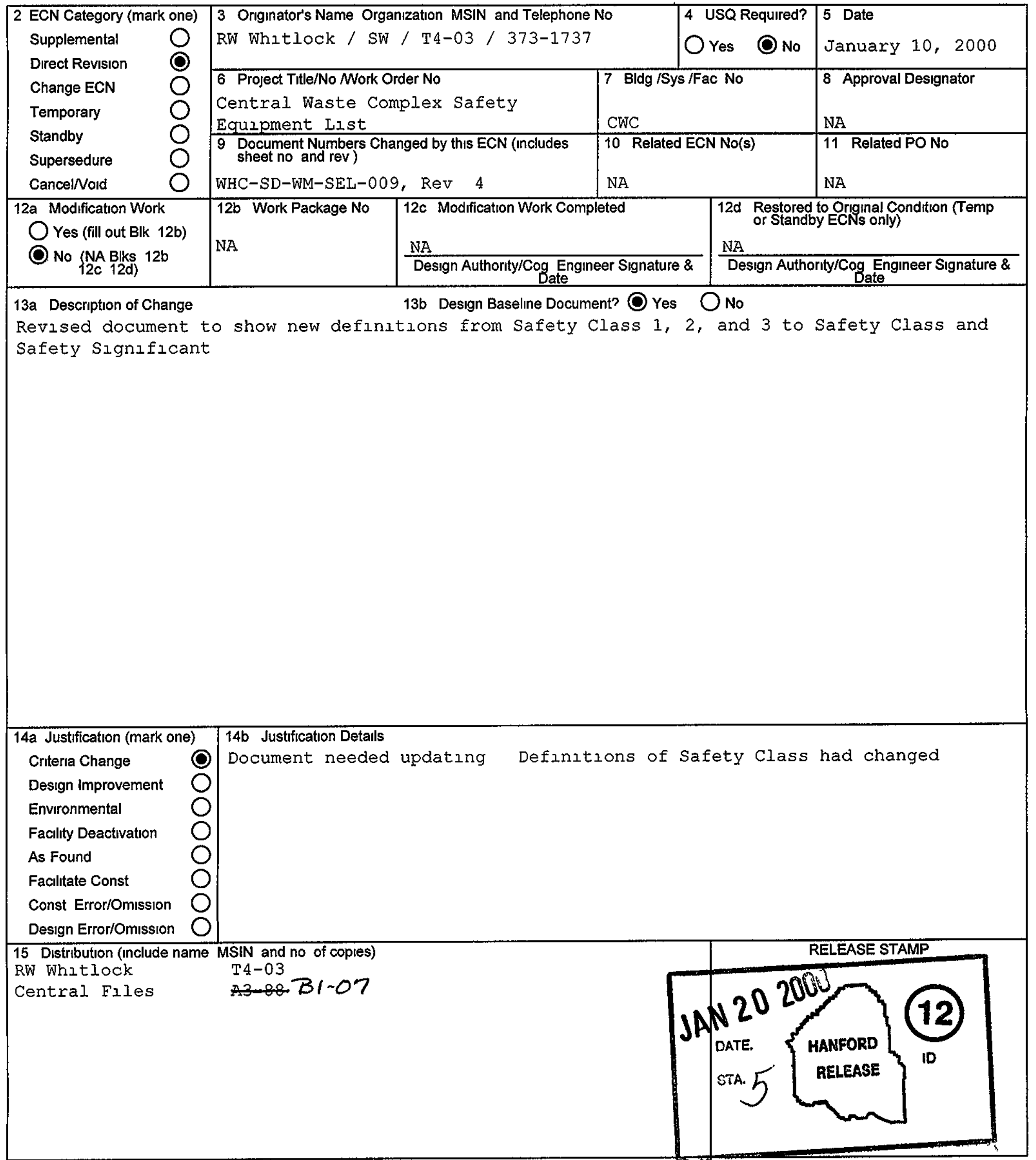




\section{ENGINEERING CHANGE NOTICE}

16 Design Verification 17 Cost Impact Required
OYes
O No

ENGINEERING

Additional $\bigcirc \$$
Page 2 of 2

\section{CONSTRUCTION}

$\begin{array}{lll}\text { Additional } & \bigcirc & \$ \\ \text { Savings } & \bigcirc & \$\end{array}$

19 Change Impact Review Indicate the related documents (other than the engineering documents identified on Side 1) that will be affected by the change described in Block 13 Enter the affected document number in Block 20

SDD/DD

Functional Design Criteria

Operatıng Specification

Criticality Specification

Conceptual Design Report

Equipment Spec

Const Spec

Procurement Spec

Vendor Information

OM Manual

FSAR/SAR

Safety Equipment List

Radiation Work Permit

Environmental Impact Statement

Environmental Report

Environmental Permit $\square$
$\square$
$\square$
$\square$
$\square$
$\square$
$\square$
$\square$
$\square$
$\square$
$\square$
$\square$
$\square$
$\square$
Sersmıc/Stress Analysıs

Stress/Design Report

Interface Control Drawing

Calibration Procedure

Installation Procedure

Maıntenance Procedure

Engıneerıng Procedure

Operating Instruction

Operating Procedure

Operational Safety Requirement

IEFD Drawing

Cell Arrangement Drawing

Essential Material Specificatıon

Fac Proc Samp Schedule

Inspection Plan

Inventory Adjustment Request $\square$
$\square$
$\square$
$\square$
$\square$
$\square$
$\square$
$\square$
$\square$
$\square$
$\square$
$\square$
$\square$
$\square$
$\square$
Tank Calıbratıon Manua! Health Physics Procedure Spares Multiple Unit Listıng

Test Procedures/Specification

Component Index

ASME Coded Item

Human Factor Consideration

Computer Software

Electric Circuit Schedule

ICRS Procedure

Process Control Manual/Plan

Process Flow Chart

Purchase Requisition

Tickier File

20 Other Affected Documents (NOTE Documents listed below will not be revised by this ECN) Signatures below indicate that the signing organization has been notified of other affected documents listed below

Document Number/Revision

Document Number/Revision

Document Number/Revision

NA

21 Approvals

Signature

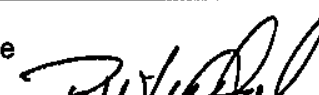

Design Authority RW whitlock TWuleftal $1 / 20100$

Cog Eng RW whrtlock KU $1 / 20 / 00$

Cog Mgr IR Rosser Aflughen

QA

Safety

Environ

Other
Design Agent

PE

QA

Safety

Design

Environ

Other

\section{DEPARTMENT OF ENERGY}

Signature or a Control Number that tracks the Approval Signature

ADDITIONAL 


\title{
Central Waste Complex Safety Equipment List
}

\author{
R W Whitlock \\ Fluor Hanford \\ Richland, WA 99352 \\ U S Department of Energy Contract DE-AC06 96RL13200
EDT/ECN $655666 \quad$ UC 512
Org Code wK000000 Charge Code 101618
B\&R Code EW3130020 Total Pages 5 \\ Key Words Central Waste Complex, Safety Equipment, Safety Class \\ Abstract This document lists all safety equipment for the Central \\ Waste Complex, per HNE-PRO-704
}

TRADEMARK DISCLAIMER Reference herein to any specific commercial product process or service by trade name trademark manufacturer or otherwise does not necessarly constitute or imply its endorsement recommendation or favoring by the United States Government or any agency thereof or its contractors or subcontractors

Printed in the United States of America To obtain copies of this document contact Document Control Services P O Box 950 Mallstop H6 08 Richland WA 99352 Phone (509) 3722420 Fax (509) 376-4989
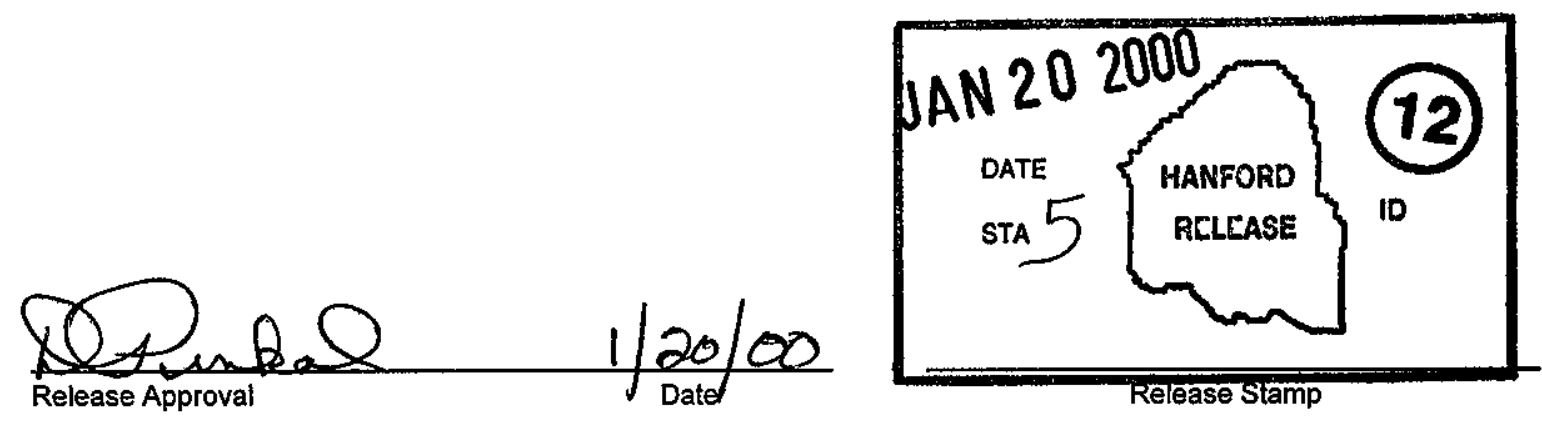

\section{Approved For Publıc Release}




\section{RECORD OF REVISION}

(2) Title

Central Waste Complex Safety Equipment List

CHANGE CONTROL RECORD

\begin{tabular}{|c|c|}
\hline (3) Revision & (4) Description of Change Replace Add and Delete Pages \\
\hline & 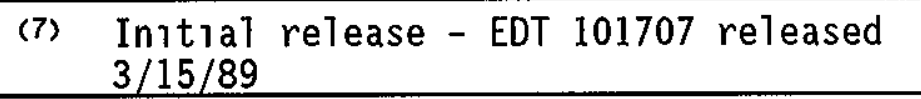 \\
\hline 2 & $\begin{array}{l}\text { This document is an update to the "CWC } \\
\text { Safety Equipment List" SD-WM-SEL-009, Rev } \\
\text { 1 per ECN 161658 }\end{array}$ \\
\hline 3 & $\begin{array}{l}\text { Delete ECN } 147283 \text { due to change in the text } \\
\text { format and deletion of the CAM's from } \\
\text { Safety Related List Incorporate ECN } \\
605626\end{array}$ \\
\hline 4 & $\begin{array}{l}\text { Document completely revised } \\
\text { ECN } 623633\end{array}$ \\
\hline $5 \mathrm{RS}$ & $\begin{array}{l}\text { Definitions of Safety Class items changed } \\
\text { Incorporated ECN } 655666\end{array}$ \\
\hline
\end{tabular}

\begin{tabular}{|l|l|}
\hline \multicolumn{3}{|c|}{ Authorized for Release } \\
\hline (5) Cog Engr & (6) Cog Mgr Date \\
& \\
& \\
\hline
\end{tabular}

Original signed by DL Armstrong $9 / 13 / 91$

Original signed by DL Armstrong 9/13/91

Original signed

by EM Megahed

Original signed by $2 / 28 / 94$

DB Powell

$2 / 28 / 94$

Original signed by VE Renard

Original signed by DB Powell 


\section{PURPOSE}

This document provides a list of structures, systems, and components that are essential to the continuing safe operation of the Central Waste Complex, as designated by the applicable facility management and the cognizant engineer

\section{CRITERIA}

A system for identification and classification of safety related equipment is established in HNF-PRO-704, Hazard and Accident Analysis Process Use of this system is required to ensure proper specification of design and quality requirement for safety related equipment

Structures, systems, and components required for safety are to be classified relative to their importance to safety and environmental protection

\section{SAFETY CLASS SSC}

Description A SSC whose preventive or mittgative function is necessary to keep radiological exposure to within the offsite radıological risk guidelınes, or to prevent a nuclear criticality

\section{SAFETY SIGNIFICANT SSC}

Description A SSC whose preventive or mitigative function is necessary to keep hazardous material exposure to within the radiological and toxic chemical risk guidelines, or is otherwise considered significant in maintaining defense-1n-depth and worker safety 


\section{SAFETY EQUIPMENT LIST}

\section{FIRE PROTECTION SYSTEM}

\section{Description}

Fire protection at the Central Waste Complex is provided by an automatic dry-pipe sprinkler system and an early warning detection system using tonization type smoke detectors

\section{Safety Classification} Class"

The safety classification of the fire system for the Central Waste Complex is "Non-Safety

\section{Justıfication}

The fire protection structures, systems, and components are controlled through an institutional safety program Fire Mantenance performs preventative maintenance on the fire system components to ensure 1ts operability

\section{CONFINEMENT SYSTEM}

\section{Description}

The confinement systems are a combination of $155 \mathrm{~cm}(6 \mathrm{mch})$ high perimeter curbs and sloped floors There are no penetrations or drains in the floors or curbs Sealed sumps are provided in some buildings for liquid collection The concrete floor is smooth and finished with a chemically resistant epoxy sealer

\section{Safety Classification}

The safety classification of the confinement systems for the Central Waste Complex is "Non Safety Class"

\section{Justification}

The confinement system structures, systems, and components are not necessary to prevent an acute fatality or serious injury to facility workers The confinement system is used to prevent a release of mixed waste to the environment 


\section{SAFETY CLASSIFICATION OF STRUCTURES, SYSTEMS, and COMPONENTS}

Currently there are no structures, systems, or components in the Central Waste Complex that meets the Safety Class or Safety Significant criteria

\section{REFERENCES}

HNF-PRO-097, Engineering Design and Evaluation

HNF-PRO-244, Engineering Data Transmittal Requirements

HNF-PRO-440, Engineering Document Change Control Requirements

HNF-PRO-488, Repair of ASME-Coded Pressure Systems

HNF-PRO-704, Hazard and Accident Analysis Process

HNF-PRO-709, Preparation and Control Standards for Engineering Drawings

HNF-PRO-1819, PHMC Engineering Requirements 